\title{
Effect of Antioxidants on the Lipid Oxidation and Flavor of Microwave-assistant Dried Silver Carp (Hypophthalmichthys molitrix) Slices
}

\author{
Xiangjin $\mathrm{Fu}^{1,2}$, Zhonghai $\mathrm{Li}^{1}$, Qinglu $\operatorname{Lin}^{1} \&$ Shiying $\mathrm{Xu}^{2}$ \\ ${ }^{1}$ School of Food science and engineering, Central South University of Forestry and Technology, Changsha, \\ China \\ ${ }^{2}$ State Key Laboratory of Food Science and Safety, Jiangnan University, Wuxi, China \\ Correspondence: Zhonghai Li, School of Food Science and Engineering, Central South University of Forestry \\ and Technology, Changsha 410004, China. E-mail: yangtzfu@yahoo.com.cn
}

Received: August 27, 2012 Accepted: Septermber 19, 2012 Online Published: October 26, 2012

doi:10.5539/jfr.v1n4p134

URL: http://dx.doi.org/10.5539/jfr.v1n4p134

\begin{abstract}
Silver carp slices were dried using microwave, and the effect of vitamin C (VC) and tea polyphenols (TP) on the quality of the dried fish slices were evaluated. The lipid oxidation, flavor, and content of fat, eicosapentaenoic (EPA), docosahexaenoic acid (DHA), earthy-musty off-odor compounds were compared among the dried slices. Marinating with VC and TP significantly protected the lipid from oxidation. Samples treated with TP $(0.2 \mathrm{~g} / 100$ $\mathrm{mL}$ ) retained the most of DHA and EPA, while restricting fishy off-odors. About $50 \%$ of geosmin and $70 \%$ of 2-methylisoborneol, the earthy-musty off-odor compounds, were removed by marinating with $\mathrm{VC}(0.4 \mathrm{~g} / 100 \mathrm{~mL})$ combined with microwave drying.
\end{abstract}

Keywords: microwave drying, vitamin C, tea polyphenols, earthy-musty, eicosapentaenoic, docosahexaenoic acid

\section{Introduction}

Silver carp (Hypophthalmichthys molitrix) is widely raised in China, India and Mexico, etc., due to its quick growth and resistance to stress, diseases and rough handling (Siddaiah, Raju, \& Chandrasekhar, 2001; Barrera, Ramirez, Gonzalez, \& Vazquez, 2002). It is a new resource for fish products, due to its huge stock (statistical data show that 4,000,000 tons were caught in China), excellent white color, low market price, high quality nutritious protein (15 18 g/100 g) and unsaturated fatty acids (Siddaiah et al., 2001; Barrera et al., 2002; Fu, Xu, \& Wang, 2009; Fu, et al., 2011; Fu, et al., 2012). However, the silver carp is not particularly liked by consumers due to its fishy and earthy-musty off-odor. The fishy odor has been attributed to the oxidation of lipid (Siddaiah et. al., 2001; Fu et al., 2009), while the earthy-musty odor is caused by the semivolatile cyclic alcohols geosmin (GEO) and 2-methylisoborneol (MIB) (Lloyd \& Grimm, 1999), which are produced by certain species of cyanophytes and actinomycetes (Andelkovic, Aleksic, \& Baltic, 2001). Thus, great effort has been made to develop value-added processed products of silver carp, such as dried fish slices.

Since microwave heating have the advantages of heating rapidly, high efficiency, good controllable and sanitation (Cui, Xu, \& Sun, 2003), many people attempted to utilize microwave in freshwater fish slices processing (Zhang, Zhang, Shan, \& Fang, 2007). Several reports have been focused on the drying of fish using microwave. The dried products were found to be more excellent in terms of taste, aroma and rehydration than products dried by the hot-air method (Zhang, et al., 2007; Wu \& Mao, 2008; Sun, Wang, \& Fu, 2012). During the drying of grass carp, microwave-dried samples showed lower fat loss, less lipid oxidation than hot air-dried samples (Wu \& Mao, 2008). In our previous study (Sun et al., 2012), silver carp slices having $80.5 \pm 0.5 \mathrm{~g} / 19.5$ $\pm 0.5 \mathrm{~g}$ (g water/g dry matter) initial moisture content were dried to a final moisture content of $20 \mathrm{~g} / 80 \mathrm{~g}$ within $10 \mathrm{~min}$ by the microwave drying at power intensity $350.0 \pm 2.0 \mathrm{~W}$; by comparison, for convective hot-air drying, it took about $150 \mathrm{~min}$ at $90{ }^{\circ} \mathrm{C}$; furthermore, the earthy-musty off-odor was reduced effectively during microwave drying; however, the odor of "Oxidated oil" still be detectable, i.e. lipid oxidation partly undergone during microwave drying.

Anti-oxidants, such as Tea polyphenols (TP) and Vitamin C (VC) have beneficial anti-oxidative activities, which 
demonstrate potential for their use as anti-oxidants in the fish slices drying. Fan, Chi and Zhang (2008) reported that TP dip treatment on silver carp lead to retention of the good quality characteristics for longer and an extension of the shelf life during iced storage. However, there have been few studies on the use of TP to protect the unsaturated fatty acids and improve the flavor of silver carp during drying.

The present work investigates the effect of anti-oxidants of TP and VC on the lipid oxidation, poly-unsaturated fatty acids (EPA and DHA) and flavor of silver carp slices during microwave drying.

\section{Materials and Methods}

\subsection{Materials}

Fresh silver carps were purchased from local market. The silver carps were brought to the laboratory on ice. The approximate weight of the individual fish was $1000 \pm 50 \mathrm{~g}$. Upon arrival to the laboratory the fish were washed, scaled, gutted, and filleted. Before drying, the white muscle was collected and cut into slices of about $5 \times 5 \times 10$ $\mathrm{mm}$ by hands and their weight were determined by an electronic balance (Model MP2000D, Shanghai Electronic Balance Instrument Co. Ltd., Shanghai, China). The average moisture content of raw slices was $80.5 \pm 0.5 \mathrm{~g} /$ $19.5 \pm 0.5 \mathrm{~g}$ (g water/g dry matter) and fat content $5.82 \pm 0.65 \mathrm{~g} / 100 \mathrm{~g}$ (g fat $/ \mathrm{g}$ dry matter).

\subsection{Marinating}

The VC and TP (Sigma Aldrich Co. Ltd, USA) were dissolved in cold distilled water $\left(4^{\circ} \mathrm{C}\right)$. The fish slices $(50 \mathrm{~g})$ were marinated in $100 \mathrm{~mL}$ solution of the VC $(0.2 \mathrm{~g} / 100 \mathrm{~mL}$ and $0.4 \mathrm{~g} / 100 \mathrm{~mL})$ or TP $(0.1 \mathrm{~g} / 100 \mathrm{~mL}$ and 0.2 $\mathrm{g} / 100 \mathrm{~mL}$ ) for $2 \mathrm{~h}$. The marinated fish slices were placed on a stainless steel wire mesh for $10 \min \left(4^{\circ} \mathrm{C}\right)$.

\subsection{Microwave Dryer}

The lab scale MD dryer in which the materials to be dried can be rotated in the cavity was developed by Cui et al. $(2003,2004)$. The rotation speed of the turntable was $5 \mathrm{rpm}$. The standard procedure described by Cui et al. (2003) was used to determine the power output. In the current study, the set power outputs of the microwave dryer was $350.0 \pm 2.0 \mathrm{~W}$.

\subsection{Drying Procedure}

Silver carp slices (marinated and non- marinated) were dried with microwave, and the hot air drying was only carried out for non- marinated fish slices as control.

Fish slices (about $10 \mathrm{~g}$ samples) were spread in a single layer in a dish made of tetrafluoroethylene and subjected to various experimental conditions:

(1) The hot air drying was conducted in an oven (Model 101-2-BS, Shanghai Yuejin Medical Instrument Co. Ltd., Shanghai, China) at $90^{\circ} \mathrm{C}$ for $2.5 \mathrm{~h}$;

(2) For microwave drying, the fish slices were heated at microwave power output of $350.0 \pm 2.0 \mathrm{~W}$ for $10 \mathrm{~min}$.

The raw samples were described as RAW; the hot air-dried samples were described as HAD; the microwave dried samples were described as MD.

\subsection{Determination of Thiobarbituric Acid Reactive Substance (TBARS)}

The TBARS was assessed according to the method of Richards and Hultin (2000). Solution of trichloroacetic acid-thiobarbituric acid (TCA-TBA) (dissolve 15g TCA and $1.3 \mathrm{~g}$ TBA in $100 \mathrm{~mL}$ water) was heated at $95^{\circ} \mathrm{C}$ for $10 \mathrm{~min}$ on the day of use to dissolve the TBA. Approximately $300 \mathrm{mg}$ of sample $(0.30 \mathrm{~mL}$ deionized water for brand) was added to $2.2 \mathrm{~mL}$ of the TCA-TBA mixture and water-bath incubated for $1 \mathrm{~h}$ at $65^{\circ} \mathrm{C}$. After centrifugation $(5000 \times \mathrm{g}$ for $10 \mathrm{~min}$ ) (model 12166, SIGMA 4K-15, German), the absorbance at $532 \mathrm{~nm}$ (SHMADZU UV-2450, Japan) of the supernatant was determined. A standard curve was constructed using malondialdehyde (MDA), and results are expressed as micrograms of MDA equivalents per kilogram of dried matter. All experiments were run in triplicates.

\subsection{Sensory Evaluation}

Five trained panelists (aged from 23 to 35, 2 male and 3 female) sniffed the samples, using a scale of 0-9 to value the odors, with 9 being the strongest (Richards \& Hultin, 2000). The average value was defined as the final score. In the training sessions assessors smelt the samples, discussing among themselves the best descriptions and agreeing on the meaning of their elected descriptors (Table 1). 
Table 1. Descriptors used in the sensory evaluation

\begin{tabular}{ll}
\hline Oxidated oil & Odour associated with rancid pork fat \\
Fishy & Odour associated with the chopped silver carp mince stand at $25^{\circ} \mathrm{C}$ for $0.5 \mathrm{~h}$ \\
Earthy/musty & Odour associated with mud \\
Grilled protein & Odour associated with grilled fish meat \\
\hline
\end{tabular}

\subsection{Determination of Fatty Acids}

About $4 \mathrm{~g}$ of each sample was homogenized for lipid extraction (Siddaiah et al., 2001). Extracted oil were analyzed for methyl esters of fatty acids by gas chromatography (Agilent 6890, USA) on a capillary column (HP 1, Agilent, USA) according to the method of $\mathrm{Wu} \&$ Mao (2008). Retention time and peak areas were recorded with the help of a microcomputer.

\subsection{Determination of Geosmin and Methylisoborneol}

The earthy-musty off-odor compounds, GEO and MIB were extracted according to the method of Lloyd \& Grimm (1999), using microwave mediated distillation and solid-phase microextraction (SPME) followed by gas chromatograph-Mass Spectrometer (GC/MS) analysis. Gas chromatograph grade GEO and MIB (Sigma Aldrich Co. Ltd, USA) were used as external standards.

The microwave mediated distillation apparatus were made according to Lloyd and Grimm (1999). The microwave oven used was a CEM (Matthews, NC) Model 300. The distillation was done at microwave power of $350 \mathrm{~W}$ for $10 \mathrm{~min}$; the flow rate of $\mathrm{N}_{2}$ was $80 \mathrm{~mL} / \mathrm{min}$. The liquid distillate was collected in a $10 \mathrm{~mL}$ glass vial. SPME fiber used was divinylbenzene/Carboxen/poly (dimethylsiloxane) (Supelco, PA, USA), and the extraction conditions were: $60{ }^{\circ} \mathrm{C}, 30 \mathrm{~min}$. GC-MS was carried out in a gas chromatography system (TRACE MS, Finnigan, USA), using the PEG-20M capillary column $(30 \mathrm{~m} \times 0.25 \mathrm{~mm} \times 0.25 \mathrm{um})$. The ion trap was operated in the electron impact (EI) ionization mode with a filament current of $10 \mathrm{~mA}$ and a mass scan range of 60 to 250 daltons.

\subsection{Statistical Analysis}

Data represent the mean and standard deviation from three independent experiments. Statistical significance of data was determined by using analysis of variance, using the SAS program, version 6.0 (SAS Institute Inc., Cary, N. C., USA.).

\section{Results}

\subsection{Effect of Antioxidants on the Lipid Oxidation during Microwave Drying}

The lipid oxidation was considerably inhibited by marinating with VC and TP (Figure 1). The final TBARS were decreased with the increasing of VC and TP. The microwave dried fish slices (MD) pretreated with TP $(0.2 \mathrm{~g} /$ $100 \mathrm{~mL})$ achieved the lowest TBARS $(0.73 \mathrm{mg} / \mathrm{kg})$.

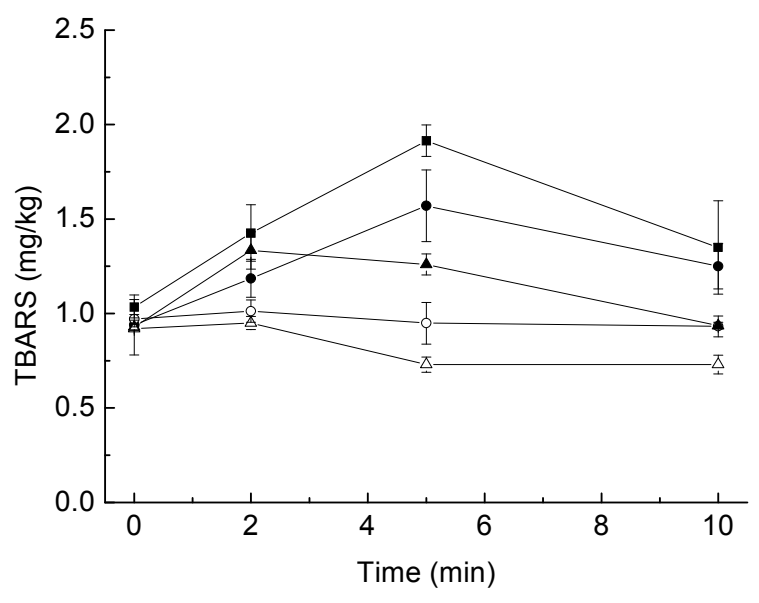

Figure 1. Effect of antioxidants on the lipid oxidation of silver carp slices during microwave drying ( $\mathbf{n}$ control; $\mathrm{VC}, 0.2 \mathrm{~g} / 100 \mathrm{~mL}$; ○ VC, $0.4 \mathrm{~g} / 100 \mathrm{~mL} ; \mathbf{\Delta} \mathrm{TP}, 0.1 \mathrm{~g} / 100 \mathrm{~mL} ; \triangle \mathrm{TP}, 0.2 \mathrm{~g} / 100 \mathrm{~mL})(\mathrm{n}=3)$

Fish slices were marinated in $\mathrm{VC}$ or $\mathrm{TP}$ solution for $2 \mathrm{~h}$, followed by being dried by microwave at power

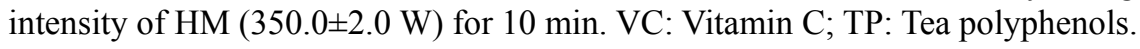




\subsection{Effect of Antioxidants on the Content of Fat, EPA and DHA}

After drying, there was a significant decrease in fat content that was revealed by the data expressed on a dry matter basis $(P<0.05)$ (Table 2). Microwave dried slices (MD) retained a higher fat content than hot air (HAD) dried samples $(P<0.05)$. All drying processes largely decreased the relative contents of EPA and DHA in silver carp slices $(P<0.05)$. The VC and TP protected the EPA and DHA effectively. The MD added TP $(0.2 \mathrm{~g} / 100$ $\mathrm{mL}$ ) showed the highest level of EPA (5.42 g/100 g fat) and DHA (4.36 g/100 g fat) (Table 2).

Table 2. Fat, EPA and DHA of dried silver carp slices

\begin{tabular}{ccccc}
\hline & $\begin{array}{c}\text { Fat (g/100g dry } \\
\text { matter) }\end{array}$ & $\begin{array}{c}\text { EPA } \\
(\mathrm{g} / 100 \mathrm{~g} \text { fat })\end{array}$ & $\begin{array}{c}\text { DHA } \\
(\mathrm{g} / 100 \mathrm{~g} \text { fat })\end{array}$ \\
\hline \multirow{3}{*}{$\mathrm{RAW}^{\mathrm{A}}$} & $5.82 \pm 0.65^{\mathrm{a}}$ & $5.08 \pm 0.09^{\mathrm{b}}$ & $3.87 \pm 0.08^{\mathrm{b}}$ \\
$\mathrm{HAD}^{\mathrm{B}}$ & $4.58 \pm 0.16^{\mathrm{c}}$ & $4.05 \pm 0.08^{\mathrm{d}}$ & $2.61 \pm 0.05^{\mathrm{c}}$ \\
$\mathrm{MD}^{\mathrm{C}}$ & $5.14 \pm 0.10^{\mathrm{b}}$ & $4.12 \pm 0.09^{\mathrm{d}}$ & $2.96 \pm 0.14^{\mathrm{c}}$ \\
& $\mathrm{VC} 0.2 \mathrm{~g} / 100 \mathrm{~mL}$ & $4.10 \pm 0.16^{\mathrm{d}}$ & $4.65 \pm 0.05^{\mathrm{c}}$ & $3.62 \pm 0.21^{\mathrm{b}}$ \\
$\mathrm{MD}^{\mathrm{D}}$ & $\mathrm{VC} 0.4 \mathrm{~g} / 100 \mathrm{~mL}$ & $4.15 \pm 0.14^{\mathrm{d}}$ & $4.98 \pm 0.15^{\mathrm{b}}$ & $3.78 \pm 0.11^{\mathrm{b}}$ \\
& $\mathrm{TP} 0.1 \mathrm{~g} / 100 \mathrm{~mL}$ & $4.78 \pm 0.15^{\mathrm{c}}$ & $4.80 \pm 0.14^{\mathrm{b}}$ & $3.85 \pm 0.08^{\mathrm{b}}$ \\
& $\mathrm{TP} 0.2 \mathrm{~g} / 100 \mathrm{~mL}$ & $4.65 \pm 0.08^{\mathrm{c}}$ & $5.42 \pm 0.11^{\mathrm{a}}$ & $4.36 \pm 0.13^{\mathrm{a}}$
\end{tabular}

${ }^{\mathrm{A}}$ Raw fish slices. ${ }^{\mathrm{B}}$ Fish slices were dried by hot air at $90{ }^{\circ} \mathrm{C}$ for $2.5 \mathrm{~h} .{ }^{\mathrm{C}}$ Fish slices were dried by microwave at $\mathrm{HM}$ (power intensity, $350.0 \pm 2.0 \mathrm{~W}$ ) for $10 \mathrm{~min} .{ }^{\mathrm{D}}$ Fish slices were marinated in VC or TP solution for $2 \mathrm{~h}$, followed by being dried by microwave at power intensity of $\mathrm{HM}(350.0 \pm 2.0 \mathrm{~W})$ for $10 \mathrm{~min}$. VC: Vitamin C; TP: Tea polyphenols.

${ }^{\mathrm{a}-\mathrm{d}}$ Means in each column having different superscript letters are significantly different $(P<0.05)(\mathrm{n}=2)$.

\subsection{Effect of Antioxidants on the Flavor of Dried Silver Carp Slices}

The odor scores of raw and dried samples are presented in Table 3. Drying increased the oxidized oil odor except for microwave dried samples (MD) with a TP pretreatment. However, drying decreased the fishy odor evidently; there was no fishy odor present in the fish slices treated with TP, especially. Furthermore, drying produced grilled protein flavor. The grilled protein flavor scores of HAD (8.4) was higher than MD (7.1) (Table 3). However, the TP treatments inhibited the increase of grilled protein flavor. The earthy-musty odor was removed slightly by drying treatments. The marinating with $\mathrm{VC}$ evidently decreased the scores of earthy-musty odor (from 4.5 to 0.4 , Table 3 ).

Table 3. Effect of drying method and antioxidants on the odour of silver carp slices

\begin{tabular}{clcccc}
\hline & Fishy & Oxidated oil & Earthy-musty & Grilled protein \\
\hline \multirow{4}{*}{$\mathrm{RAW}^{\mathrm{A}}$} & 5.0 & 1.0 & 4.5 & 0 \\
& $\mathrm{HAD}^{\mathrm{B}}$ & 2.2 & 3.8 & 3.8 & 8.4 \\
& $\mathrm{MD}^{\mathrm{C}}$ & 2.6 & 3.7 & 1.9 & 7.1 \\
& $\mathrm{VC} 0.2 \mathrm{~g} / 100 \mathrm{~mL}$ & 2.3 & 2.4 & 1.1 & 6.2 \\
$\mathrm{MD}^{\mathrm{D}}$ & $\mathrm{VC} 0.4 \mathrm{~g} / 100 \mathrm{~mL}$ & 1.2 & 1.2 & 0.4 & 6.9 \\
& $\mathrm{TP} 0.1 \mathrm{~g} / 100 \mathrm{~mL}$ & 0 & 1.0 & 1.6 & 3.5 \\
& $\mathrm{TP} 0.2 \mathrm{~g} / 100 \mathrm{~mL}$ & 0 & 0.5 & 1.5 & 3.4 \\
\hline
\end{tabular}

The odour was valued using a scale of $0-9$, with 9 being the strongest.

${ }^{\mathrm{A}}$ Raw fish slices. ${ }^{\mathrm{B}}$ Fish slices dried by hot air at $90{ }^{\circ} \mathrm{C}$ for $2.5 \mathrm{~h} .{ }^{\mathrm{C}}$ Fish slices dried by microwave at HM (power intensity, $350.0 \pm 2.0 \mathrm{~W}$ ) for $10 \mathrm{~min} .{ }^{\mathrm{D}}$ Fish slices were marinated in $\mathrm{VC}$ or TP solution for $2 \mathrm{~h}$, followed by being dried by microwave at power intensity of HM $(350.0 \pm 2.0 \mathrm{~W})$ for $10 \mathrm{~min}$. VC: Vitamin C; TP: Tea polyphenols. 


\subsection{The Content of Earthy-musty Compounds}

Quantitative information of MIB and GEO from the integrated peak areas using external standard plots is shown in Table 4. The result revealed the concentration of the off-odor compounds at $2.31 \pm 0.25 \mathrm{ug} / \mathrm{kg} \mathrm{MIB}$ and $1.29 \pm$ $0.15 \mathrm{ug} / \mathrm{kg}$ GEO for RAW (raw fish). The treatment of $\mathrm{VC}(0.4 \mathrm{~g} / 100 \mathrm{~mL})$ combined with microwave drying reduced about MIB to $0.63 \pm 0.12 \mathrm{ug} / \mathrm{kg}$ ( $70 \%$ reduction) and GEO to $0.57 \pm 0.08 \mathrm{ug} / \mathrm{kg}$ (50\% reduction).

Table 4. The effect of drying method and pretreatment with VC on the content of earthy-musty compounds MIB and GEO (ug/kg)

\begin{tabular}{ccc}
\hline & MIB & GEO \\
\hline RAW $^{\mathrm{A}}$ & $2.31 \pm 0.25^{\mathrm{a}}$ & $1.29 \pm 0.15^{\mathrm{a}}$ \\
$\mathrm{MD}^{\mathrm{B}}$ & $2.62 \pm 0.20^{\mathrm{a}}$ & $0.85 \pm 0.11^{\mathrm{b}}$ \\
$\mathrm{MD}^{\mathrm{C}}(\mathrm{VC} 0.4 \mathrm{~g} / 100 \mathrm{~mL})$ & $0.63 \pm 0.12^{\mathrm{b}}$ & $0.57 \pm 0.08^{\mathrm{c}}$
\end{tabular}

${ }^{\mathrm{A}}$ Raw fish slices. ${ }^{\mathrm{B}}$ Fish slices dried by microwave at power intensity of HM $(350.0 \pm 2.0 \mathrm{~W})$ for $10 \mathrm{~min},{ }^{\mathrm{C}}$ Fish slices were marinated in $\mathrm{VC}$ solution $(0.4 \mathrm{~g} / 100 \mathrm{~mL})$ for $2 \mathrm{~h}$, followed being dried by microwave at power intensity of HM $(350.0 \pm 2.0 \mathrm{~W})$ for $10 \mathrm{~min}$. VC: Vitamin C.

${ }^{\mathrm{a}-\mathrm{c}}$ Means in each column having different superscript letters are significantly different $(P<0.05)(\mathrm{n}=2)$.

\section{Discussions}

\subsection{Lipid Oxidation}

Peroxide value defines the initial stage of the oxidative changes. However, peroxides are unstable and decompose via fission, dehydration and the formation of free radicals, to form a variety of chemical products, such as alcohols, aldehydes, ketones, and acids compounds at elevated temperatures, and thus, peroxide value was found to be a poor indicator for heated samples (Wu \& Mao, 2008). Alternatively, TBARS (thiobarbituric acid reactive substance) value could be reliable and meaningful for evaluating the fat quality of heated samples. And previous study (Siddaiah et al, 2001) found the significantly positively relationship between TBARS and off-odor in silver carp, thus, the present study used TBARS to evaluate the intensity of the lipid oxidation.

Thermal oxidation is one of the greatest threats to unsaturated fatty acids in foods. The EPA and DHA are especially susceptible to oxidation. The oxidations of unsaturated fat acids are catalyzed by heat, light, trace metals or enzymes and involve free radical generation (Turhan, Ustun, \& Altunkaynak, 2004). Free radicals propagate autooxidation by reacting with oxygen to form hydroperoxides, which breakdown to generate other new free radicals (Weber, Bochi, Ribeiro, Victorio, \& Emanuelli, 2008) and TBARS (Stewart, Raghavan, Orsat, \& Golden, 2003).

High temperatures accompanying drying processes could speed up the breakdown of peroxides into their carbonyl components, the temperature of samples during microwave drying were lower that of hot air drying (Sun et al., 2012), thus the TBARS of the dried fish slices was higher during hot air drying than microwave drying (Table 2). Thus, the slices dried by microwave obtained lower TBARS.

The antioxidants, VC and TP, exhibited a good ability of anti-oxidation (Figure 1). This is explained by the fact that VC and TP have potent free radical quenching activity. The TP has been used to inhibit the increase of TBARS of silver carp fillets during ice storage, after approximately 35 days of iced storage, the final TBARS was $0.85 \mathrm{mg} / \mathrm{kg}$, while the samples without TP had $3.09 \mathrm{mg} / \mathrm{kg}$ TBARS (Fan et al., 2008). In the present study, the microwave dried fish slices (MD) pretreated with TP $(0.2 \mathrm{~g} / 100 \mathrm{~mL})$ achieve the lowest TBARS of 0.73 $\mathrm{mg} / \mathrm{kg}$ (Figure 1), that is of great practical importance, provides a possible application of microwave drying as an efficient drying process for fish slices.

\subsection{Content of Fat Acids, EPA and DHA}

Drying decreased the content of fat, EPA and DHA. Microwave dried slices (MD) retained higher content of fat, EPA and DHA than hot air (HAD) $(P<0.05)$ (Table 2). Similar results were achieved by other researchers (Stewart et al., 2003) for soybean. Weber et al. (2008) also observed cooking led to a fat loss, when compared to the raw silver catfish. The loss of volatile free fat acids probably occurred during heating, leading to a decreased fat content. Furthermore, fat may exude with the moisture evaporation. The extended heating treatment during hot air drying seems to enhance this phenomenon. On the other hand, oxidation is another way the fat is lost. 
According to the results of lipid oxidation (Figure 1), the fat lose is in accordance with increased lipid oxidation, except in the case of MD samples treated with VC, which retained the lowest content of fat (Table 2) while limiting lipid oxidation, since part of fat was lost in the marinating stage (data not shown). The TP protected the EPA and DHA effectively may be due to the TP inhibit the lipid oxidation (Figure 1), with its structural features that may specifically interfere with the unsaturated fat acid cascade (Banerjee, 2006).

\subsection{Flavor of Dried Silver Carp Slices}

Cooking methods have significant effect on the flavor of foods. The grilled protein flavor is the favored aroma. The HAD (8.4) fish samples received higher score of grilled protein flavor than MD (7.1) (Table 2) which may due to the high temperature during hot air drying, since the products of Millard reaction occur at high temperatures and they have been shown to contribute to a "meat-like" flavor (Weber et al., 2008).

The "oxidated oil" and "fishy odor" notes are caused by aldehydes and ketones, which are the products of lipid oxidation; and there is a significantly positively relationship between TBARS and off-odor in silver carp (Siddaiah et al., 2001). Two mg TBARS/kg is usually regarded as the limit beyond which the fish will normally develop an objectionable odor (Fan et al., 2008). The VC and TP treatments reduced the fishy and oxidated oil off-odor because they effectively protected the lipid from oxidation (TBARS $<1.5 \mathrm{mg} / \mathrm{kg}$ ) (Figure 1).

\subsection{Earthy-musty Odor}

Earthy-musty odor in fresh water-farmed fish represents one of the most significant economic problems encountered in aquaculture. It is suggested that differences between acceptability of silver carp from different ponds may be due to earthy-musty off-odor resulting from the presence of GEO and MIB in the pond environment, when either compound is present in tissue at concentrations exceeding $0.7 \mathrm{ug} / \mathrm{kg}$, they render fish unfit for retail sale (Andelkovic, Aleksic, \& Baltic, 2001). Attempts to mask harvested tainted fish with chemical treatments, various cooking methods and flavorings have achieved limited success (Yamprayoon \& Noomhorm, 2000).

After drying, these undesirable odorous compounds were partially removed, but slight taint still existed (Table 4). Because GEO and MIB are lipophilic compounds, and fish have fat, their removal is very difficult.

The treatment of VC $(0.4 \mathrm{~g} / 100 \mathrm{~mL})$ combined with microwave drying reduced about $70 \% \mathrm{MIB}$ and $50 \%$ GEO (Table 4). Yamprayoon and Noomhorm (2000) reported that marinating tilapia in acetic acid solution resulted in decreased earthy-musty odor, partly because the acid enhances the desorbing of MIB and GEO from the muscle proteins, partly because the acid marinating treatment remove considerable fat from the muscle, so the fat-soluble MIB and GEO were removed too. The VC is an acidic substance (ascorbic acid) which may play a similar role as acetic acid in removing the earthy-musty odor compounds of silver carp slices.

\section{Conclusions}

Silver carp slices were dried using microwave, and the effect of vitamin C (VC) and tea polyphenols (TP) on the quality of the dried fish slices were evaluated. The marinating with VC and TP significantly inhibited the lipid oxidation during drying. Samples treated with TP $(0.2 \mathrm{~g} / 100 \mathrm{~mL})$ retained the most of DHA and EPA while preventing the production of fishy off-odors. A large part of the earthy-musty off-odor compounds were removed by marinating with $\mathrm{VC}(0.4 \mathrm{~g} / 100 \mathrm{~mL})$ combined with microwave drying.

\section{Acknowledgement}

This work was supported by "Youth Scientific research fundation of central south university of forestry and technology".

\section{References}

Andelkovic, R., Aleksic J., \& Baltic, M. (2001). The investigation of the acceptability of carp and silver carp meat from different ponds. Tehnologija Mesa, 42, 33-38.

Banerjee, S. (2006). Inhibition of mackerel (Scomber scombrus) muscle lipoxygenase by green tea polyphenols. Food Research International, 39, 486-491. http://dx.doi.org/10.1016/j.foodres.2005.10.002

Barrera, A. M., Ramirez, J. A., Gonzalez, C. J. J., \& Vazquez, M. (2002). Effect of pectins on the gelling properties of surimi from silver carp. Food hydrocolloid, 16, 441-447. http://dx.doi.org/10.1016/S0268-005X(01)00121-7

Cui, Z. W., Xu, S. Y., \& Sun, D. W. (2003). Dehydration of garlic slices by combined microwave-vacuum and air drying. Drying Technology, 21(7), 1173-1185. http://dx.doi.org/10.1081/DRT-120023174

Cui, Z. W., Xu, S. Y., \& Sun, D. W. (2004). Microwave-vacuum drying kinetics of carrot slices. Journal of Food 
Engineering, 65, 157-164. http://dx.doi.org/10.1016/j.jfoodeng.2004.01.008

Fan, W. J., Chi, Y. L., \& Zhang, S. (2008). The use of a tea polyphenol dip to extend the shelf life of silver carp (Hypophthalmicthys molitrix) during storage in ice. Food Chemistry, 108, 148-153. http://dx.doi.org/10.1016/j.foodchem.2007.10.057

Fu, X., Hayat, K., Li, Z., Lin, Q., Xu, S., \& Wang, S. (2012). Effect of microwave heating on the low-salt gel from silver carp (Hypophthalmichthys molitrix) surimi. Food hydrocolloid, 27(2), 301-308 http://dx.doi.org/10.1016/j.foodhyd.2011.09.009

Fu, X., Li, Z., Lin, Q., Xu, S., \& Kim, J. (2011). Effect of pH-shifting treatment on the Biochemical and thermal properties of myofibril protein. Advanced Materials Research, 236-238, 2231-2235. http://dx.doi.org/10.4028/www.scientific.net/AMR.236-238.2231

Fu, X., Xu, S., \& Wang, Z. (2009). Kinetics of lipid oxidation and off-odor formation in silver carp mince: the effect of lipoxygenase and hemoglobin. Food research international, 42, 85-90. http://dx.doi.org/10.1016/j.foodres.2008.09.004

Lloyd, S. W., \& Grimm, C. C. (1999). Analysis of 2-methylisoborneol and geosmin in catfish by microwave distillation-solid-phase microextraction. Journal of Agricultural \& Food Chemistry, 47, 164-169. http://dx.doi.org/10.1021/jf980419x

Richards, M. P., \& Hultin, H. O. (2000). Effect of $\mathrm{pH}$ on lipid oxidation using trout hemolysate as a catalyst: a possible role for deoxyhemoglobins. Journal of Agricultural \& Food Chemistry, 48, 3141-3147. http://dx.doi.org/10.1021/jf991059w

Siddaiah, D., Reddy, G. V. S., Raju, C. V., \& Chandrasekhar, T. C. (2001). Changes in lipids, proteins and kamaboko forming ability of silver carp (Hypophthalmichthys molitrix) mince during frozen storage. Food Research International, 34(1), 47-53. http://dx.doi.org/10.1016/S0963-9969(00)00127-7

Stewart, O. J., Raghavan, G. S. V., Orsat, V. \& Golden, K. D. (2003). The effect of drying on unsaturated fatty acids and trypsin inhibitor activity in soybean. Process Biochemistry, 39, 483-489. http://dx.doi.org/10.1016/S0032-9592(03)00130-4

Sun, Y., Wang, W., \& Fu, X. (2012). Effect of Drying Method on the Quality of Silver Carp Slices. Food science, 33(10), 16-19.

Turhan, S., Ustun, N. S., \& Altunkaynak, T. B. (2004). Effect of cooking methods on total and heme iron contents of anchovy (Engraulis encrasicholus). Food Chemistry, 88, 169-172. http://dx.doi.org/10.1016/j.foodchem.2004.01.026

Weber, J., Bochi, V. C., Ribeiro, C. P., Victorio, A. de M., \& Emanuelli, T. (2008). Effect of different cooking methods on the oxidation, proximate and fatty acid composition of silver catfish (Rhamdia quelen) fillets. Food Chemistry, 106, 140-146. http://dx.doi.org/10.1016/j.foodchem.2007.05.052

$\mathrm{Wu}, \mathrm{T}$., \& Mao, L. (2008). Influences of hot air drying and microwave drying on nutritional and odorous properties of grass carp (Ctenopharyngodon idellus) fillets. Food Chemistry, 110, 647-653. http://dx.doi.org/10.1016/j.foodchem.2008.02.058

Yamprayoon, J., \& Noomhorm, A. (2000). Effects of preservation methods on geosmin content and off-flavor in Nile tilapia (Oreochromis niloticus). Journal of Aquatic Food Product Technology, 9(4), 95-107. http://dx.doi.org/10.1300/J030v09n04_09 